\title{
出血胃潰瘍の手術適応に関する臨床的研究
}

\author{
東京女子医科大学消化器病センター
}

横堀直孝

\section{A CLINICAL STUDY ON THE INDICATION OF OPERATION FOR BLEEDING GASTRIC ULCERS}

\section{Naotaka YOKOBORI}

The Institute of Gastroenterology, Tokyo Women's Medical College

\begin{abstract}
出血胃潰瘍111例について時間的経過に着目し，入院を起点とした場合と出血を起点とした場合とに分 けて臨床的検討を行った.

出血胃潰瘍では出血を起点とした時間的経過が予後に大きな関係をもち，80歳以上を除く高齢者におい ては, 術前合併症, あるいはショックの有無にかかからず, 出血から48時間未満に手術を行った症例の手 術成績が最も良好で, ついで48時間以上7日未満のものの手術成績が良好であった。

このような事実に基づいて, 出血胃潰瘍の手術にあたっては性と年龄, 出血回数, 出血から手術までの 期間, 輸血量, ショック, 術前合併症, 術式, 術後合併症を考虑し, 出血を起点とした時間的経過に着目 して手術適応を決定することが望ましいといら結果をえた。
\end{abstract}

索引用語: 出血胃潰掦, 手術死亡, 出血から手術までの期間, 術前合併症, 手術適応

\section{I. 緒言}

胃出血はとの頻度も高く，時に不幸な転機をとり，速 かな処置を要求される重要な胃潰湟合併症である。この 胃出血に対する診断と治療の進歩により, 出血, 寸なわ ち手術といら考え方は現在かならずしる容認されている あのではないが，急性大量出血例に対しては外科的治療 が問題となる. 今日です急性大量胃出血に対する外科的 適応は明確でなく, 出血胃潰痬の外科的治療成績は決し て良好とはいえない.いま胃出血の手術適応についてみ ると，長尾 ${ }^{1)}$ は輸血によって失われた循環血液量を補 い, その全身反応の仕方によって胃出血を軽症, 中等 症, 重症の 3 型に分類し, $1,000 \mathrm{ml}$ 程度までの急速輸 血によってもショックの改善のきざしをみない重症型は 早期手術の対象とし, 軽症，中等症には待機手術とする 方針をとっている.井ロ ${ }^{2)}$ は出血患者でショック，ある いはショック準備状態のものが来院したら，まず500〜 1,000 ml の輸血を急速に行い, 循環系が安定すれば経過 を観察してもよいが，依然として循環系不安定状態が続 くよらであれば手術を積極的に考えるというやり方が妥
当であろらとしている．また,ひとたび止血しても,24〜 48時間以内に出血が再発する場合には, ショックになら なくても手術にふみきることになるらと述べている．紙

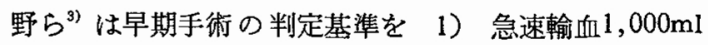
をこえるも, ショックから回復しない場合．2） 1,000 $\mathrm{ml}$ 以内の輸血で, ショックから回復した後に, 最高血 圧 $100 \sim 200 \mathrm{mmHg}$, 脈圧 $20 \mathrm{mmHg}$ 以上の維持に, なお 輸血が12時間以上必要な場合. 3） $1,000 \mathrm{ml}$ 以内の輸血 で, ショックから回復した後に, 再度, 出血ショックが 起こった場合. 4) 観察期間を48時間以内として, その 間に血圧の不安定な変化を示し, 脈圧が $20 \mathrm{mmHg}$ 以上 を維持できない場合と述べている. 一方, Ivy ら 血後 $48 \sim 72$ 時間以内の手術を早期手術とし, それ以後の 手術を後期手術として死亡率を比較している. Dalichau $5^{5)}$ は出血開始後48時間以内を早期手術といっている. 日本人に果してこれらの時間的経過をるって手術適応を 決めうるであろらか。 また出血量から手術適応を決めよ らとする報告でも，一応，早期手術，待機手術などの言 葉を用いているが，その時間的経過についてはまったく 
述べられていないそこで，この手術適応関する時間 的経過の問題を検討するために解析をこころみた。

\section{II. 検索対象症例および検索方法}

検索対象症例は東京女子医大消化器病センターに打い て, 昭和44年から昭和50年までに手術された出血胃潰瘦 症例のらち, 入院前 3 ケ末満に顕性出血のみられた 111例である

検討症例のらち, 入院を起点として48時間未満に手術 が行われた $\mathrm{A}$ ，48時間以上 7 日未満に手術が行われた B，および 7 日以上経過して手術が行われたC 検討した.

さらにAおよび Bについて, 出血を起点として48時間 未満に手術が行われた a，48時間以上 7 日未満に手術が 行われた b，および 7 日以上経過して手術が行われた $\mathrm{c}$ に分けて検討した。

検索方法はつぎの項目について検討した.すなわち， 性と年齢, 出血回数, 出血から手術むでの期間, 輸血 量, 手術とショック, 術前合併症, 術式, 術後合併症で ある。

\section{III. 検查成繶}

\section{1. 入院を起点とした検索症例}

i ) 性と年齢

入院を起点とした検索症例の性と年齡との関係は表 1 に示すと拉りである.Aの男女比は5：1で男性が多 く，年齢では60歳代が最も多く36例中14例，38.9\%を占 める.ついで50歳代が 8 例， $22.2 \%$ である. 死亡例はす べて男性で60歳代 3 例， 70 歳代 2 例，80歳代 1 例であ る. Bの男女比は2.75：1で男性が多い。年齢では70歳 代が最も多く 15 例中 5 例，33.3\%である.ついで50歳代
が 4 例，26.7\%である. 死亡例はすべて男性で50歳代 1 例，60歳代 1 例，80歳代 1 例である. そしてCの男女比 は4：1で男性が多い，年齢では50歳代と60歳代とが最 も多く，ともに60例中 17 例 $28.3 \%$ でる.ついで40藏代 の11例，18.3\%である. 死亡例はない.

ii ) 出血回数

出血回数は次のように数えた。最初に顕出血があっ て，胃ゾンデで止血を確認したとき 1 回出血とした。な お，䫓出血を主訴としているが入院時止血しているるの む1 回出血とした. 胃ゾンデから出血が続き止血が確認 されないものは持続出血とした．また，止血が確認され ず吐血あるいは下血を絽り返す場合，さらに，顕出血 後輸血をしても胃ゾンデから出血があり,ショック状態 が続いているものも持続出血とした，最初の顕出血後， 胃ゾンデで止血が 確認され，一般状態の安定をみたの ち, 再び大量の吐下血をみる場合, ショックが起こっ た場合, 留置胃ゾンデから再出血が確認された場合は 2 回出血とした. 以下同じょうに 3 回出血, 4 回出血とし た.

出血回数は表 2 亿示すと㓠りである.Aで 2 回出血が 最も多く36例中 12 例 $33.3 \%$, ういで持続出血，1回出血 および 3 回出血がそれぞれ7例，19.4\%である。Bで3 回出血と 4 回出血が最も多く、それぞれ15例中 3 例, 20 \%,ついで 2 回出血，7回出血がそれぞれ 2 例，13.3\% である.Cで1回出血が最も多く60例中 49 例， $81.7 \%$, ついで 2 回出血の 7 例， $11.7 \%$ である.

死亡例についてみれば，Aで持続出血に 7 例中 1 例, $14.3 \% ， 2$ 回出血に 12 例中 3 例， $25 \% ， 3$ 回出血に 7 例 中 2 例， $28.6 \%$ の死亡がみられる. 1 回出血，4回出

表 1 珄と年令

\begin{tabular}{|c|c|c|c|c|c|c|c|c|}
\hline & \multicolumn{2}{|c|}{ A } & \multicolumn{2}{|c|}{ B } & \multicolumn{2}{|c|}{$\mathrm{C}$} & & \\
\hline 年令 性 & $\hat{o}$ & ㅇ & $\hat{\delta}$ & f & $\hat{\delta}$ & 우 & 計 & 年令別死亡率 \\
\hline$\sim 19$ & 0 & 0 & 1 & 0 & 0 & 0 & 1 & $0 \%$ \\
\hline $20 \sim 29$ & 0 & 0 & 1 & 0 & 4 & 0 & 5 & $0 \%$ \\
\hline $30 \sim 39$ & 2 & 0 & 0 & 0 & 5 & 3 & 10 & $0 \%$ \\
\hline $40 \sim 49$ & 5 & 1 & 1 & 0 & 11 & 0 & 18 & $0 \%$ \\
\hline $50 \sim 59$ & 7 & 1 & $3(1)$ & 1 & 13 & 4 & 29 & $3.4 \%(1 / 29)$ \\
\hline $60 \sim 69$ & $11(3)$ & 3 & $2(1)$ & 0 & 14 & 3 & 33 & $12.1 \%(4 / 33)$ \\
\hline $70 \sim 79$ & $4(2)$ & 1 & 2 & 3 & 1 & 2 & 13 & $15.4 \%(2 / 13)$ \\
\hline $80 \sim$ & $1(1)$ & 0 & $1(1)$ & 0 & 0 & 0 & 2 & $100 \%(2 / 2)$ \\
\hline 計 & 30 & 6 & 11 & 4 & 48 & 12 & 111 & \\
\hline
\end{tabular}


表 2 出血回数

\begin{tabular}{|c|c|c|c|c|c|}
\hline 出血回数 & A & B & $\mathrm{C}$ & 計 & 死亡率 \% \\
\hline 持続 & $7(1)$ & 1 & 3 & 11 & $9.1 \%(1 / 11)$ \\
\hline 1 [而 & 7 & 1 & 49 & 57 & $0 \%$ \\
\hline $2 " \prime$ & $12(3)$ & $2(1)$ & 7 & 21 & $19.0 \%(4 / 21)$ \\
\hline $3 \prime \prime$ & $7(2)$ & 3 & 1 & 11 & $18.2 \%(2 / 11)$ \\
\hline $4 \prime \prime$ & 2 & 3 & 0 & 5 & $0 \%$ \\
\hline $5 \prime \prime$ & 1 & 1 & 0 & 2 & $0 \%$ \\
\hline $6 "$ & 0 & $1(1)$ & 0 & 1 & $100 \%(1 / 1)$ \\
\hline $7 \prime \prime$ & 0 & $2(1)$ & 0 & 2 & $50 \%(1 / 2)$ \\
\hline $8 \prime \prime$ & 0 & 0 & 0 & 0 & $0 \%$ \\
\hline $9 \prime \prime$ & 0 & 1 & 0 & 1 & $0 \%$ \\
\hline it & 36 & 15 & 60 & 111 & \\
\hline
\end{tabular}

表 3 出血開始から手術むでの期間

\begin{tabular}{|c|c|c|c|}
\hline $\begin{array}{l}\text { 出血開始から } \\
\text { 手術での期間 }\end{array}$ & A 36例 & B 15例 & C 60 例 \\
\hline 24時間末満 & 6 & 0 & 0 \\
\hline 24 時間以上 48 時間末満 & $5(1)$ & 0 & 0 \\
\hline 2 日以上 3 日未満 & 2 & 2 & 0 \\
\hline 3 日” 4 日” & 2 & 1 & 0 \\
\hline 4 日” 5 日” & $2(1)$ & 2 & 0 \\
\hline 5 日” 6 日” & $\cdot 2(2)$ & 0 & 0 \\
\hline 6 日”7 7 日” & 2 & 1 & 0 \\
\hline 1 週" 2 週 " & 4 & $4(1)$ & 15 \\
\hline 2 週" 1 月 " & $5(1)$ & 3 & 13 \\
\hline 1 月" 3 月 " & $6(1)$ & $2(2)$ & 32 \\
\hline 入院からみた死亡率 & $\begin{array}{l}16.7 \% \\
(6 / 36)\end{array}$ & $\begin{array}{c}20 \% \\
(3 / 15)\end{array}$ & $0 \%$ \\
\hline
\end{tabular}

血，5回出血には死亡が 認められていない，Bで2回 出血に 2 例中 1 例， $50 \% ， 6$ 回出血飞 1 例中 1 例， 100 $\% ， 7$ 回出血飞 2 例中 1 例，50\%の死亡がみられる. 持 続出血, 1 回出血, 3 回出血, 4 回出血, 5 回出血, 9 回出血には死亡はみられない，Cには死亡がない。

iii）出血から手術までの期間

出血が始まった時点から手術までの期間は表 3 に示す とおりである.Aで 1 週未満が最も多く36例中 21 例 58.3 $\%$ ，ついで 1 月以上 3 月末満が 6 例， $16.7 \% ， 2$ 週以上 1 月末満が 5 例， $13.9 \%$ である. 死亡例は 1 週未満で 21 例中 4 例， $19.0 \% ， 2$ 週以上 1 月末満で 5 例中 1 例， 20 $\% ， 1$ 月以上 3 月末満で 6 例中 1 例， $16.7 \%$ みられる. Bで 1 週未満が最も多く 15 例中 6 例， $40 \%$ ，ついで 1 週 以上 2 週未満が 4 例， $26.7 \%$ である. 死亡例は 1 週以上 2 週末満で 4 例中 1 例， $25 \% ， 1$ 月以上 3 月未満で 2 例 中 2 例， $100 \%$ である. Cでは 1 月以上 3 月未満が 60 例
中32例， $53.3 \%$ と最も多く, ついで 1 週以上 2 週末満が 15 例， $25 \% ， 2$ 週以上 1 月末満が13例， $21.7 \%$ である. 死亡例は認められない。

\section{iv) 輸血量}

輸血量は術前，術中，術後に分けて検討した。それら の輸血量は表 4 亿示すとおりである.

\section{表 4 翰 血 量}

\begin{tabular}{|c|c|c|c|c|c|c|c|}
\hline & $\begin{array}{c}\text { 輸血量 } \\
\text { ml }\end{array}$ & $\begin{array}{c}\mathrm{A} \\
36 \text { 例 }\end{array}$ & 平均 & $\begin{array}{c}B \\
15 \text { 例 }\end{array}$ & 平均 & $\underset{60 \text { 例 }}{\mathrm{C}}$ & 平均 \\
\hline \multirow{2}{*}{ 術前 } & $\begin{array}{r}1000 \mathrm{ml} \\
\text { 未満 }\end{array}$ & $17(2)$ & \multirow{2}{*}{$\begin{array}{r}1194 \\
\mathrm{ml}\end{array}$} & 3 & \multirow{2}{*}{$\begin{array}{r}2280 \\
\mathrm{ml}\end{array}$} & 32 & \multirow{2}{*}{$\begin{array}{r}893 \\
\mathrm{~m}\end{array}$} \\
\hline & $\begin{array}{l}1000 \mathrm{ml} \\
\text { 以上. }\end{array}$ & $19(4)$ & & $12(3)$ & & 28 & \\
\hline \multirow{2}{*}{ 術中 } & $\begin{array}{r}1000 \mathrm{ml} \\
\text { 未満 }\end{array}$ & $18(2)$ & \multirow{2}{*}{$\begin{array}{r}1006 \\
\mathrm{ml}\end{array}$} & 11 & \multirow{2}{*}{$\begin{array}{r}827 \\
\mathrm{ml}\end{array}$} & 59 & \multirow{2}{*}{$\begin{array}{r}157 \\
\mathrm{ml}\end{array}$} \\
\hline & $\begin{array}{l}1000 \mathrm{ml} \\
\text { 以上 }\end{array}$ & $18(4)$ & & $4(3)$ & & 1 & \\
\hline \multirow{2}{*}{ 術後 } & $\begin{array}{r}1000 \mathrm{ml} \\
\text { 未满 }\end{array}$ & $23(4)$ & \multirow{2}{*}{$\begin{array}{r}850 \\
\mathrm{ml}\end{array}$} & $12(3)$ & \multirow{2}{*}{$\begin{array}{r}560 \\
\mathrm{ml}\end{array}$} & 60 & \multirow{2}{*}{$\begin{array}{c}53 \\
\mathrm{ml}\end{array}$} \\
\hline & $\begin{array}{l}1000 \mathrm{ml} \\
\text { 以上 }\end{array}$ & $13(2)$ & & 3 & & 0 & \\
\hline
\end{tabular}

術前の輸血量は A で1, $000 \mathrm{ml}$ 以上が多く 36 例中19例, $52.8 \%$ を占め, 平均 $1,194 \mathrm{ml}$ である. 死亡例は $1,000 \mathrm{ml}$ 末満に 17 例中 2 例, $11.8 \%, 1,000 \mathrm{ml}$ 以上飞 19 例中 4 例， $21.1 \%$ みられる．Bで $1,000 \mathrm{ml}$ 以上が多く 15 例中 12 例， $80 \%$ を占め, 平均 $2,280 \mathrm{ml}$ である。死亡例は 1,000 $\mathrm{ml}$ 以上K 12 例中 3 例， $25 \%$ みられる. Cで1,000 $\mathrm{ml}$ 末 満が多く60例中 32 例， $53.3 \%$ を占め，平均 $893 \mathrm{ml}$ であ る. 死亡例はない，術前翰血量は平均すると， B $>A>C$ の順である。

術中 輸血量をみると，Aで1,000 $\mathrm{ml}$ 末満と $1,000 \mathrm{ml}$ 以上とが等しく18例づつで，平均 $1,006 \mathrm{ml}$ である. 死亡 例は $1,000 \mathrm{ml}$ 末満に 18 例中 2 例, $11.1 \%, 1,000 \mathrm{ml}$ 以上 に18例中 4 例， $22.2 \%$ みられる.Bで1,000 $\mathrm{ml}$ 末満が多 く 15 例中 11 例， $73.3 \%$ を占め，平均 $827 \mathrm{ml}$ である. 死亡 例は $1,000 \mathrm{ml}$ 以上飞 4 例中 3 例， $75 \%$ みられる.Cで $1,000 \mathrm{ml}$ 末満が多く60例中59例， $98.3 \%$ を占め，平均 $157 \mathrm{ml}$ である. 死亡例はない. 術中の平均 $157 \mathrm{ml}$ である. 死亡例はない，術中の平均輸血量は $\mathrm{A}>\mathrm{B}>\mathrm{C}$ の順であ る.

術後の輸血量をみ礼ば，Aで1,000 $\mathrm{ml}$ 末満が多く36例 中23例， $63.9 \%$ を占め, 平均 $850 \mathrm{ml}$ で㐫る. 死亡例は $1,000 \mathrm{ml}$ 末満に23例中 4 例， $17.4 \%, 1,000 \mathrm{ml}$ 以上飞 13 例中 2 例， $15.4 \%$ みられる.Bでl,000 $\mathrm{ml}$ 末満が多く 15例中 12 例， $80 \%$ を占め，平均 $560 \mathrm{ml}$ である. 死亡例は $1,000 \mathrm{ml}$ 末満に 12 例中 3 例， $25 \%$ みられる.Cで全例が 
表 5 手術とショック

\begin{tabular}{|c|c|c|c|}
\hline 手術直前の状態 & A 36 例 & B 15例 & C 60 例 \\
\hline $\begin{array}{c}* ョ ッ ク(+) \\
\rightarrow \text { 手術 }\end{array}$ & $23\left(\begin{array}{c}6 \text { 例 } \\
21.6 \%\end{array}\right)$ & $5\left(\begin{array}{cc}1 & \text { 例 } \\
20 \%\end{array}\right)$ & 0 \\
\hline 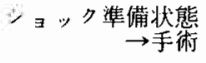 & 7 & $5\left(\begin{array}{c}2 \text { 例 } \\
40 \%\end{array}\right)$ & 0 \\
\hline 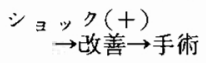 & 4 & 5 & 13 \\
\hline ンョック(一) & 2 & 0 & 47 \\
\hline
\end{tabular}

$1,000 \mathrm{ml}$ 末満で, 平均 $53 \mathrm{ml}$ である. 死亡例はない. 術 後の平均輸血量は $\mathrm{A}>\mathrm{B}>\mathrm{C}$ の順である.

v) 手術とショック

手術とショックの関係は表 5 に示すとおりである。A でショックが改善されぬまま手術を行ったものが最も多 く36例中23例，63.9\%を占め，ショック準備状態で手術 を行ったものが 7 例, $19.4 \%$ 占める. ショックが改善 され手術を行ったものは 4 例 $11.1 \%$ を占め, ショックが みられなかったものは 2 例， $5.6 \%$ にすぎなかった。死 亡例はショックが改善されぬまま手術が行われた症例に 23例中 6 例, $26.1 \%$ みられる. Bでショックが改善され ぬまま手術が行われたもの, ショック準備状態で手術が 行われたもの,ショックが改善され手術が行われたもの がそれぞれ等しく15例中 5 例，33.3\%を占め, ショック のみられなかった症例はない. 死亡例はショックの改善 されぬまま手術が行われた症例に 5 例中 1 例, 20\%, シ ヨック準備状態で手術が行われた症例に 5 例中 2 例， 40 \%みられる、Cでショックのみられないものが多く60例 中47例, 78.3\%を占め, ショックが改善され手術が行わ れた症例は13例 $21.7 \%$ を占める。死亡例はない。

vi) 術前合併症

術前合併症は表6-1, 表6-2に示すとおりであ る. 合併症を併存するものはBで最も多く15例中12例， 80\%を占める.Aで35例中20例，57.1\%（ただし，不明 の 1 例を除く）を占め, Cで60例中 21 例 $35 \%$ を占める. 術前合併症のみられる率は $\mathrm{B}>\mathrm{A}>\mathrm{C}>$ の順である.

疾患のらちわけを蔵器別にみると, 狭心症, 心筋硬 塞, 心不全, 弁膜疾患, 不整脈などの心疾患 はA 66 例，Bに 5 例，Cに 2 例みられる.肺疾患はAに 1 例, $\mathrm{B}$ 例，Cに 4 例ある. 肝疾患は $\mathrm{A} に 3$ 例, Cに 1 例 ある.腎疾患隐性腎不全でAK 1 例, B 1 例, C 1

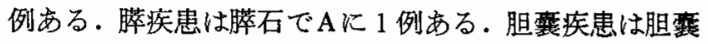
結石でCに 1 例める. 糖尿病はAK 1 例, Bに 2 例, Cに
表 6-1 術前合併症

\begin{tabular}{|c|c|c|c|c|}
\hline \multicolumn{2}{|c|}{ 術前合併症 } & A 36例 & B 15例 & C 60 例 \\
\hline あ & $\eta$ & $20(5)$ & $12(3)$ & 21 \\
\hline な & L & $15(1)$ & 3 & 39 \\
\hline 下 & 明 & 1 & 0 & 0 \\
\hline
\end{tabular}

表 6-2 術前合併症の疾患別頻度

\begin{tabular}{l|l|l|l}
\hline \hline 疾 患 名 & A & B & C \\
\hline 心 疾 患 & $6(3)$ & $5(3)$ & 2 \\
肺 疾 患 & 1 & $2(1)$ & 4 \\
肝 疾 患 & $3(1)$ & 0 & 1 \\
腎 疾 患 & $1(1)$ & 1 & 1 \\
腪 疾 患 & 1 & 0 & 0 \\
胆の5疾患 & 0 & 0 & 1 \\
糖 尿 病 & 1 & 2 & 5 \\
高 血 王 & $7(2)$ & $4(1)$ & 6 \\
出血前の手術 & 3 & 2 & 1 \\
その他の疾患 & $5(2)$ & $4(2)$ & 7 \\
\hline
\end{tabular}

（）内死亡例にみられた術前合併症数

5 例ある. 出血前に行われた手術はAに 3 例みられ, 直 腸癌根治手術, 前立腺癌根治手術, 冠動脈バイパス手術 である. Bで 2 例みられ, 子宮癌根治術, 白内障手術であ る.Cで1例みられ，鼻中隔矯正術である．その他の疾 患にはリゥマチ, 脳軟化症などの各種の疾患を含めた. 合併症併存症例の死亡率は B で12例中 3 例，25\%, A で20例中 5 例，25\%で，Cに死亡はない。

死亡例の術前合併症は器質的心疾患が多く9 例中 6 例 に認められる. 高血圧は 3 例, 肺疾患は 1 例認められ る. 心疾患を合併する症例の死亡率はAで 6 例中 3 例, $50 \%$ ，Bで 5 例中 3 例，60\%，Cで0\%である。高血圧 症を合併する症例の死亡率はA で 7 例中 2 例， $28.6 \%$, Bで 4 例中 1 例， $25 \% ， \mathrm{C}$ で0\%である.肺疾患を合併 する症例の死亡率はBで 2 例中 1 例，50\%であるが， A，C で0\%である. 死亡例は 9 例中 6 例をでが同時に 2つ以上の異なる合併症をもっていた。

vii) 術式

表 7 術 式

\begin{tabular}{l|c|c|c}
\hline \hline \multicolumn{1}{c|}{ 術 式 } & A 36例 & B 15例 & C 60例 \\
\hline 幽門側切除術 & $32(5)$ & $14(3)$ & 55 \\
噴門側切除術 & 3 & 1 & 3 \\
全 摘 術 & 0 & 0 & 2 \\
姑息 (揳状) 切除術 & $1(1)$ & 0 & 0 \\
\hline \multicolumn{4}{|r}{}
\end{tabular}


術式は表 7 に示すとおりである。Aで幽門側切除が最 む多く32例を占め，噴門側切除が 3 例，姑息切除が 1 例 みられる，Bで幽門側切除が14例，噴門側切除が 1 例み られる。Cで幽門側切除が最も多く55例，噴門側切除が 3 例，全摘が 2 例みられる.

viii）術後合併症

術後合併症は表 8-1 扰よび表 8-2 亿示すと打りで ある。術後合併症はAで36例中15例，41.7\%，Bで15例 中 8 例 $53.3 \% ， \mathrm{C} て ゙ 60$ 例中 1 例，1.7\%にみられる.

表 8-1 術後合併症

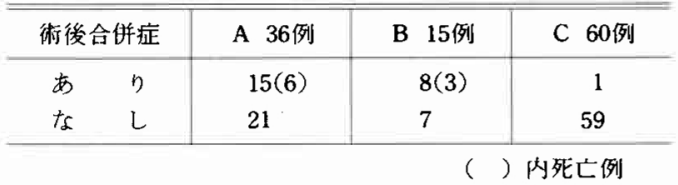

表 8-2 術後合併症の疾患別頻度

\begin{tabular}{|c|c|c|c|}
\hline 疾 患 名 & A & B & C \\
\hline 心 疾 患 & $5(5)$ & $3(2)$ & 0 \\
\hline 肺 疾 患 & $3(2)$ & $2(1)$ & 0 \\
\hline 肝 疾 患 & 6 & 1 & 1 \\
\hline 腎 疾 患 & $1(1)$ & $2(1)$ & 0 \\
\hline 縫合不全 & 2 & $4(2)$ & 0 \\
\hline 術後出血 & $3(1)$ & 2 & 0 \\
\hline イレウス & 1 & 3 & 0 \\
\hline その他の疾患 & $2(1)$ & 2 & 0 \\
\hline
\end{tabular}

（）内死亡例にみられた術後合併症数

術後合併症沁心不全, 狭心症発作, 心室細動, 急性心 停止，肺炎，血清肝资，尿毒症，急性腎不全などであ る.Aで肝炎が最も多く36例中 6 例，16.7\%，心疾患は 5 例，13.9\%，つぎに肺炎と術後出血とがそれぞれ 3 例 8.3\%を示している。縫合不全は 2 例，5.6\%である. B

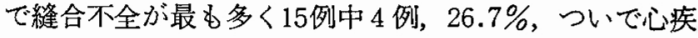
患が 3 例, $20 \%$, 肺炎, 術後出血, 腎疾患がそれぞれ 2 例， $13.3 \%$ を示している，Cで肝炎が60例中 1 例，1.7 \%を示している。

$\mathrm{A}$ と B とを対比してみると，BではAより高頻度に心 疾患がみられ，縫合不全や術後出血も高頻度にみられ る.とくに縫合不全は百分率でAの 4 倍強の頻度であ る.肺炎，腎疾患もやはりBに高頻度にみられる．肝炎 はA の異なる術後合併症を併発したが， B の死亡例では 3 例 中 2 例であった。

2. 出血を起点とした手術時期別検討
入院を起点として検討した結果，A と B に問題がある ことがわかった，そこで同一の病期の症例を比較するた めに出血を起点としてAとBを検討した。ここで，これ らについて出血を起点として手術までの期間が48時間末 満を a，48時間以上 7 日未満を b，7 日以上を c に分预 た。

\section{i ) 性と年龄}

a,b,c の性と年龄は表 9 亿示すと括りである，a は男 女比が2.7:1で男性が多い, 60歳代が最も多く11例中 5 例，45.5\%を占め，ついで50藏代が 3 例，27.3\%であ る。死亡例は80歳代の男性に1例みられる。 b は男女比 が $3: 1$ で男性が多い. 50 歳代が最も多く16例中 5 例,

表 9 性と年令

\begin{tabular}{|c|c|c|c|c|c|c|}
\hline & \multicolumn{2}{|c|}{ a } & \multicolumn{2}{|c|}{ b } & \multicolumn{2}{|c|}{ c } \\
\hline 年令 性 & $\hat{o}$ & 우 & $\hat{\delta}$ & 우 & 今े & 우 \\
\hline$\sim 19$ & 0 & 0 & 1 & 0 & 0 & 0 \\
\hline $20 \sim 29$ & 0 & 0 & 0 & 0 & 1 & 0 \\
\hline $30 \sim 39$ & 0 & 0 & 1 & 0 & 1 & 0 \\
\hline $40 \sim 49$ & 1 & 0 & 3 & 0 & 2 & 1 \\
\hline $50 \sim 59$ & 3 & 0 & 3 & 2 & $4(1)$ & 0 \\
\hline $60 \sim 69$ & 3 & 2 & $3(2)$ & 1 & $7(2)$ & 0 \\
\hline $70 \sim 79$ & 0 & 1 & $1(1)$ & 1 & $5(1)$ & 2 \\
\hline $80 \sim$ & $1(1)$ & 0 & 0 & 0 & 1(1) & 0 \\
\hline 計 & 8 & 3 & 12 & 4 & 21 & 3 \\
\hline 死亡率 \% & \multicolumn{2}{|c|}{$9.1 \%(1 / 11)$} & \multicolumn{2}{|c|}{$18.8 \%(3 / 16)$} & \multicolumn{2}{|c|}{$20.8 \%(5 / 24)$} \\
\hline
\end{tabular}

$31.3 \%$ を占め，ついで60歳代 が 4 例 $25 \% ， 40$ 歳代が 3 例，18.8\%を占める. 死亡例は60歳代 2 例，70歳代 1 例 で，すべて男性である。c の男女比は7：1で男性が多 い. 60 歳代と70歳代とが最も多くそれぞれ24例中 7 例, $29.2 \%$ を占め，ついで50歳代が 4 例16.7\%をを占める. 死 亡例は50歳代 1 例，60歳代 2 例，70歳代 1 例，80歳代 1 例で，すべて男性である。

ii ) 出血回数

a,b,c の出血回数は表10に示すと括りである、aで2 回出血が最も多く 11 例中 4 例，36.4\%を占め，ついで 1 回出血が 3 例， $27.3 \%$, 持続出血が 2 例， $18.2 \%$ を占め ている. 2 回出血で80歳代の症例が 1 例死亡している. b では持続出血， 1 回出血から 2 回以上の出血までひる がってみられた．持続出血 1 例，2回出血 1 例，そして 3 回出血に 1 例の死亡がみられた. Cでは 2 回，3回出 血が最も多くそれぞれ24例中 7 例，29.2\%を占め，つい で持続出血，1回出血がそれぞれ 3 例，12.5\%を占め 
表10 出血回数

\begin{tabular}{c|l|l|l}
\hline \hline 出血回数 & $\mathrm{a}$ & $\mathrm{b}$ & $\mathrm{c}$ \\
\hline 持続 & 2 & $3(1)$ & 3 \\
1 回 & 3 & 2 & 3 \\
$2 \prime \prime$ & 4 & $3(1)$ & $7(2)$ \\
$3 \prime \prime$ & $1(1)$ & $2(1)$ & $7(1)$ \\
$4 \prime \prime$ & 1 & 3 & 1 \\
$5 \prime \prime$ & 0 & 2 & 0 \\
$6 "$ & 0 & 0 & $1(1)$ \\
$7 "$ & 0 & 0 & $2(1)$ \\
$8 \prime \prime$ & 0 & 0 & 0 \\
$9 "$ & 0 & 1 & 0 \\
\hline "計 & 11 & 16 & 24 \\
\hline \multicolumn{4}{|l|}{}
\end{tabular}

表11 出血開始から手術までの期間

\begin{tabular}{|c|c|c|c|}
\hline $\begin{array}{l}\text { 出血開始から期間 } \\
\text { 手術ざ }\end{array}$ & a & b & $\mathrm{c}$ \\
\hline $\begin{array}{c}24 \text { 時問末来満 } \\
24 \text { 時間以上 } 488 \text { 㭙間末末満 }\end{array}$ & $\begin{array}{l}6 \\
5(1)\end{array}$ & & \\
\hline $\begin{array}{l}2 \text { 日以上 } 3 \text { 日未満 } \\
3 \text { 日” } 4 \text { 日”" } \\
4 \text { 日” } 5 \text { 日”" } \\
5 \text { 日” } 6 \text { 日” } \\
6 \text { 日” } 7 \text { 日” }\end{array}$ & & $\begin{array}{l}4 \\
3 \\
4(1) \\
2(2) \\
3\end{array}$ & \\
\hline $\begin{array}{l}1 \text { 週以上 } 2 \text { 週未満 } \\
2 \text { 週以上 } 1 \text { 月未満 } \\
1 \text { 月以上 } 3 \text { 月未満 }\end{array}$ & & & $\begin{array}{l}8(1) \\
8(1) \\
8(3)\end{array}$ \\
\hline 計 & 11 & 16 & 24 \\
\hline 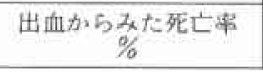 & $\begin{array}{l}9.1 \% \\
(1 / 11)\end{array}$ & $\begin{array}{l}18,8 \% \\
(3 / 16)\end{array}$ & $\begin{array}{l}20.8 \% \\
(5 / 24)\end{array}$ \\
\hline
\end{tabular}

( ) 内死亡数

る. 2 回出血 2 例， 3 回出血 1 例， 6 回出血 1 例，そし て 7 回出血 1 例に死亡が浔められた.

\section{iii) 手術までの期間}

a,b,c の出血から手術までの期間は表11に示すと拈り である. a は出血から24時間未満に手術が行われた症例 が多く11例中 6 例 $54.5 \%$ を占める. 24 時間以上 48 時間未 満の手術施行症例に 80 歳の死亡を 1 例認める. b は 2 日 以上 3 日未満と 4 日以上 5 日未満とが多くそれぞれ16例 中 4 例, $25 \%$ を占める. 死亡は 4 日以上 5 日末満に 4 例中 1 例，25\%，5 日以上 6 日未満に 2 例中 2 例， 100 \%認められる。cは 1 週以上 2 週未満, 2 週以上 1 月末 满, 1 月以上 3 月末満の症例がそれぞれ等しく24例中 8 例, $33.3 \%$ を占め, 死亡は 1 週以上 2 週未満に 8 例中 1 例， $12.5 \% ， 2$ 週以上 1 月未満に 8 例中 1 例， $12.5 \%$, 1 月以上 3 月末満に 8 例中 3 例, $37.5 \%$ みらる. iv) 輸血量 a,b,c の輸血量を術前, 術中, 術後に分けて検討し た.それらの輸血量は表12 亿示すとおりである.術前の 輸血量をみれば，a で1, $000 \mathrm{ml}$ 以上が多く 11 例中 7 例, $63.6 \%$ を占め, 平均 $1,036 \mathrm{ml}$ である. 死亡は $1,000 \mathrm{ml}$ 以 上に 1 例みられる. b では $1,000 \mathrm{ml}$ 末満と $1,000 \mathrm{ml}$ 以上 が等しく 8 例 づつで, 平均 $1,850 \mathrm{ml}$ である. 死亡は $1,000 \mathrm{ml}$ 未満に 8 例中 1 例, $12.5 \%, 1,000 \mathrm{ml}$ 以上に 8 例中 2 例， $25 \%$ みれる。cで $1,000 \mathrm{ml}$ 以上が多く 24例中16例， $66.7 \%$ を占め, 平均1,499ml である. 死亡 はl, $000 \mathrm{ml}$ 末満に 8 例中 1 例， $12.5 \%, 1,000 \mathrm{ml}$ 以上 に16例中 4 例， $25 \%$ みられる. 術前の平均翰血量は b>c>a の順である.

表12輸 血 量

\begin{tabular}{|c|c|c|c|c|c|c|c|}
\hline & & $\begin{array}{c}a \\
11 \text { 例 }\end{array}$ & 平均 & $\begin{array}{c}\mathrm{b} \\
16 \text { 例 }\end{array}$ & 平均 & $\begin{array}{c}c \\
24 \text { 例 }\end{array}$ & 平均 \\
\hline \multirow{2}{*}{ 術前 } & $\begin{array}{r}1000 \mathrm{ml} \\
\text { 未満 }\end{array}$ & 4 & \multirow{2}{*}{$\begin{array}{r}1036 \\
\mathrm{ml}\end{array}$} & $8(1)$ & \multirow{2}{*}{$\begin{array}{r}1850 \\
\mathrm{ml}\end{array}$} & $8(1)$ & \multirow{2}{*}{$\begin{array}{r}1499 \\
\mathrm{~m}\end{array}$} \\
\hline & $\begin{array}{c}1000 \mathrm{ml} \\
\text { 以上 }\end{array}$ & $7(1)$ & & $8(2)$ & & $16(4)$ & \\
\hline \multirow{2}{*}{ 術中 } & $\begin{array}{r}1000 \mathrm{ml} \\
\text { 未満 }\end{array}$ & $7(1)$ & \multirow{2}{*}{$\begin{array}{r}855 \\
\mathrm{ml}\end{array}$} & $9(1)$ & \multirow{2}{*}{$\begin{array}{c}981 \\
\mathrm{ml}\end{array}$} & $13(2)$ & \multirow{2}{*}{$\begin{array}{c}889 \\
\text { m }\end{array}$} \\
\hline & $\begin{array}{c}1000 \mathrm{ml} \\
\text { 以上 }\end{array}$ & 4 & & $7(2)$ & & $11(3)$ & \\
\hline \multirow{2}{*}{ 術後 } & $\begin{array}{r}1000 \mathrm{ml} \\
\text { 未満 }\end{array}$ & $6(1)$ & \multirow{2}{*}{$\begin{array}{r}1218 \\
\mathrm{ml}\end{array}$} & $12(2)$ & \multirow{2}{*}{$\begin{array}{r}688 \\
\mathrm{ml}\end{array}$} & $17(4)$ & \multirow{2}{*}{$\begin{array}{r}610 \\
\mathrm{ml}\end{array}$} \\
\hline & $\begin{array}{c}1000 \mathrm{ml} \\
\text { 以上 }\end{array}$ & 5 & & $4(1)$ & & $7(1)$ & \\
\hline
\end{tabular}

術中の輸血量をみれば, a で1,000 $\mathrm{ml}$ 末満が多く 11 例中 7 例， $63.6 \%$ を占め, 平均 $855 \mathrm{ml}$ である. 死亡は $1,000 \mathrm{mI}$ 末満に 1 例みられる.b で1,000 ml 未満が多 く16例中 9 例， $56.3 \%$ を占め, 平均 $981 \mathrm{ml}$ である. 死亡 は1,000 $\mathrm{ml}$ 末満に 9 例中 1 例, $11.1 \%, 1,000 \mathrm{ml}$ 以上に 7 例中 2 例, $28.6 \%$ みられる. c で1,000 ml 未満が多く 24 例中13例， $54.2 \%$ を占め，平均 $889 \mathrm{ml}$ である. 死亡は $1,000 \mathrm{ml}$ 末満に 13 例中 2 例， $15.4 \%, 1,000 \mathrm{ml}$ 以上に 11 例中 3 例, $27.3 \%$ みられる. 術中の平均輸血量は $b>c$ $>$ a の順である.

術後の輸血量をみると, a で $1,000 \mathrm{ml}$ 末満が多く11例 中 6 例, $54.5 \%$ を占め, 平均 $1,218 \mathrm{ml}$ である. 死亡は $1,000 \mathrm{ml}$ 末満に 1 例みられる.bで $1,000 \mathrm{ml}$ 末満が多 く16例中12例， $75 \%$ を占め, 平均 $688 \mathrm{ml}$ である. 死亡は $1,000 \mathrm{ml}$ 末満に 12 例中 2 例， $16.7 \%, 1,000 \mathrm{ml}$ 以上に 4 例中 1 例, $25 \%$ みられる.c で1,000 $\mathrm{ml}$ 末満が多く 24 例中17例, $70.8 \%$ を占め, 平均 $610 \mathrm{ml}$ である. 死亡は $1,000 \mathrm{ml}$ 未満に 17 例中 4 例， $23.5 \%, 1,000 \mathrm{ml}$ 以上に 7 
例中 1 例， $14.3 \%$ みららる。術後の平均輸血量は $a>b$ $>c$ の順である。

v) 手術とショック

$\mathrm{a}, \mathrm{b}, \mathrm{c}$ の手術とショックの関係は表13に示すとおりで ある.ショックが改善されぬまま手術が行われた症例は a で11例中 8 例，bで16例中10例，そしてcで24例中10 例である. a で 8 例中 1 例， $12.5 \%, \mathrm{~b}$ で10例中 3 例, $30 \%$ ，cで10例中 3 例30\%の死亡率を示している.

表13手術とショック

\begin{tabular}{|c|c|c|c|}
\hline 手術直前の状態 & a & b & c \\
\hline ショック(+) & $8(1)$ & $10(3)$ & $10(3)$ \\
\hline ンョック準備状態 & 1 & 3 & $8(2)$ \\
\hline 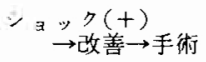 & 1 & 3 & 5 \\
\hline ンョック(一) & 1 & 0 & 1 \\
\hline 計 & 11 & 16 & 24 \\
\hline
\end{tabular}

ショック準備状態で手術が行われた症例は aで1例， bで 3 例， c で 8 例認められるが，a，bには死亡がなく， cで 8 例中 2 例，25\%の死亡率がみられる.

ショックが改善され手術が行われた症例は、で1例，

b で 3 例，c で 5 例みられるが，死亡はない。

ショックがみられなかった症例は aで 1 例， c で 1 例 みられるが, 死亡はない。

vi) 術前合併症

a,b,c の術前合併症は表14一1および表14-2 亿示す とおりである。術前合併症のある症例は、で10例中 8 例，80\%（ただし，合併症不明の 1 例を除く）, bで16例 中 9 例, $56.3 \%$ ，c で24例中15例， $62.5 \%$ を占める. 術 前合併症の併存率は $a>c>b$ の順である. 術前合併症 のある症例の 死亡率は $\mathrm{a}$ で 8 例中 1 例, $12.5 \%$, b で 9 例中 3 例， $33.3 \% ， \mathrm{c}$ で15例中 3 例，20\%である. 死亡 率は $\mathrm{b}>\mathrm{c}>\mathrm{a}$ の順である。術前合併症のない症例の 死亡率は a で0\%, bで0\%，そしてcで 9 例中 2 例， $22.2 \%$ である.cのみに死亡がみられる．器質的心疾患 の合併はaで2例認められるが，死亡していない，bで 3 例認められ全例死亡している。cで 6 例認められ 3 例，50\%が死亡している。

vii) 術式

a,b,c の術式は表15に示すとおりである.aで11例中 8 例が幽門側切除を施行されている，そのほか噴門側切
表14- 1 術前合併症

\begin{tabular}{cc|l|l|c}
\hline \hline \multicolumn{2}{c|}{ 術前合併症 } & a 11例 & b 16例 & c 24例 \\
\hline あ & b & $8(1)$ & $9(3)$ & $15(3)$ \\
な & L & 2 & 7 & $9(2)$ \\
ホ & 明 & 1 & 0 & 0 \\
\hline \multicolumn{2}{l}{}
\end{tabular}

表14- 2 術前合併症疾患別頻度

\begin{tabular}{|c|c|c|c|}
\hline 疾 患 名 & a & b & c \\
\hline 心疾 患 & 2 & $3(3)$ & $6(3)$ \\
\hline 肺 疾 患 & 0 & 1 & $2(1)$ \\
\hline 肝 疾 患 & $2(1)$ & 1 & 0 \\
\hline 腎 患 & $1(1)$ & 1 & 0 \\
\hline 䐙 疾 患 & 0 & 0 & 1 \\
\hline 槚 疗 病 & 1 & 1 & 1 \\
\hline 高 血 珐 & 2 & 5 & 4 \\
\hline 出血前の手術 & 2 & 1 & 2 \\
\hline その他の疾患 & 2 & $1(1)$ & $6(1)$ \\
\hline
\end{tabular}

表15 術 式

\begin{tabular}{c|c|c|c}
\hline \hline \multicolumn{1}{c|}{ 術 } & $\mathrm{a}$ & $\mathrm{b}$ & $\mathrm{c}$ \\
\hline 幽門側切除術 & 8 & $16(3)$ & $22(5)$ \\
噴門側切除術 & 2 & 0 & 2 \\
全 摘 術 & 0 & 0 & 0 \\
姑息 (揳状) 切除術 & $1(1)$ & 0 & \\
\hline & 11 & 16 & 24 \\
\hline
\end{tabular}

除が 2 例，揳状切除が 1 例行われている. 死亡は契状切 除にみられる。bで全例が幽門側切除を施行されてい る. 死亡は 3 例みられる.cで幽門側切除が多く24例中 22例，91.7\%を占め，噴門側切除が 2 例，8.3\%である. 死亡は幽門側切除に 5 例みられるが，噴門側切除にはみ られない。

viii) 術後合併症

a,b,c の術後合併症は表16一1，および表16-2に示 すと括りである。

術後合併症 は a で11例中 6 例，54.5\%，bで16例中 5 例， $31.3 \% ， c$ で24例中 12 例，50\%にみられる。

a で肝疾患が最も多く11例中 3 例にみられ，ついで縫 合不全が11例中 2 例みられる。 bで心疾患が最も多く16 例中 2 例みられ, 肺疾患, 腎疾患, 縫合不全, 術後出血 などがそれぞれ 1 例みられる.cで心疾患が最も多く24 例中 5 例みられ，ついで肺疾患，肝疾患がそれ発れ 4 
表16- 1 術後合併症

\begin{tabular}{cc|c|c|c}
\hline \hline \multicolumn{2}{c|}{ 術後合併症 } & $\mathrm{a}$ 11例 & $\mathrm{b}$ 16例 & $\mathrm{c} 24$ 例 \\
\hline あ & $\eta$ & $6(1)$ & $5(3)$ & $12(5)$ \\
な & $\iota$ & 5 & 11 & 12 \\
\hline \multicolumn{4}{r|r}{}
\end{tabular}

表16-2 術後合併症疾患別頻度

\begin{tabular}{ll|l|l|l}
\hline \hline 疾 患 & 名 & $\mathrm{a}$ & $\mathrm{b}$ & $\mathrm{c}$ \\
\hline 心 疾 患 & $1(1)$ & $2(2)$ & $5(4)$ \\
肺 疾 患 & 0 & $1(1)$ & $4(2)$ \\
肝 疾 患 & 3 & 0 & 4 \\
腎 疾 患 & 0 & $1(1)$ & $2(1)$ \\
縫 合不全 & 2 & 1 & $3(2)$ \\
術 後出 血 & 1 & $1(1)$ & 3 \\
イ レ & 1 & 1 & 2 \\
そ の 他 & $1(1)$ & 1 & 2 \\
\hline
\end{tabular}

（）内死亡例にみられた術後合併症数

例みられる。

\section{IV. 考祭}

胃出血はその頻度も高く，時に不幸な転機をとり，速 かな処置を必要とする重要な胃潰瘍合併症であり，とく に外科的治療が問題となるものである。その手術適応に つてて 古くから多くの意見がある，長尾"，井口 ${ }^{2)}$, 紙野 ${ }^{3)}$ らは輸血によって循環血液量を補い，その全身反 応の仕方によって適応を決めようとの意見を発表してい る.この適応決定の方法は一見合目的にみ兄るが，たと えば輸血量についても，またその時間的経過についても 大きな幅があり，結局は経験に頼らざるをえないようで ある. 一方, Ivyら ${ }^{4)}$ は出血後の時間的経過を重視し, 手術適応を決めようとの考皇をもっている，しかし，体 格の異なる日本人について，また諸外国では十二指腸潰 瘍の多いことから，ただちに彼らの時間的経過による適 応を用いることはできないように思われる，そこでこの 手術適応に関する時間的経過の問題を検討しようとし た. 時間的経過を検討するに際して, 時間的経過の起点 が問題になる。もっとも明瞭な起点の 1 つは入院であ り, 他の 1 つ㤕血発症であろう. そこで時間的経過を みるに際して，入院を起点としたものと，出血を起点と したものとの 2 つに分けて検索し，さらに，どちらを起 点に適応決定をなすべきかを検討した。

まず性についてみれば，A,B,C 技よび a,b,c 各群とも に男性が多かった。出血性潰瘍は男性が女性より多いと いら報告が注とんどであることに一致し，また死亡はす べて男性例であったことは性が入院から，あるいは出血
から手術までの時間的経過に関する因子であるとはいい がたいよらに思われる。

Ivyら ${ }^{6)}$ は諸家の報告を集計した結果，10歳未澫の死 亡率は $0 \% ， 10$ 歳代は 4\%，20歳代 は5.8\%，30歳代は $7 \% ， 40$ 歳代 は11\%，50歳代 は13.6\%，60歳代は15.7 \%，70歳代は $16.5 \% ， 80$ 歳代は50\%という成績をえて年 歯とともに死亡率る高くなると述べている。また Cock $ら^{7)}$ は胃十二指腸潰瘍の緊急手術死亡率を80歳以上で44 \%と述べているが, Baker ${ }^{8)}$, Jones ${ }^{9)}$ は80歳以上の手術死 亡率をそれぞれ100\%，0\%といるいる報告している。 しかし，入院から手術までの時間的経過を考慮したもの はない、いま自験例を検討してみると，Aでは60歳代が 多く，Bでは70歳代が多く，Cでは若年者が多い。死亡 例はA,Bに9例認められ全例が男珄である。Cに死亡 は認められない，年齢とともに死亡率も高くなってい る. a で80歳代，b で60歳代，70歳代，c で50歳代， 60 歳代，70歳代および80歳代に死亡がみられ，時間の経過 が長くなるにつれて年齢の若いものが加わってくる傾向 である、a の死亡例が 80 歳例ということがとくに注目さ れる. 80 歳代は年龄を考慮すれぱ，時間的経過からする 適応から除外されるべさであると考えられる。

出血回数についてみれば, Bockus ${ }^{10)}$ ，Ivy ら ${ }^{6)}$ は持続出 血，あるいは再出血が致命的結果の前兆となると述べて いる. Chiesman ${ }^{11}$ らも再出血のない症例の死亡率は持 続出血，あるいは再出血をきたした症例の死亡率よりは るかに低いことを報告している。このように再出血，あ るいは持続出血が問題となる。しかし，これらの報告は 時間的経過についてふれていない，いま自験例について みると, 2 回以上の出血例の死亡率はA で22例中 5 例, $22.7 \%$ ，Bで13例中 3 例，23.1\%で大差がみられない のに反し, $\mathrm{a}$ で 6 例中 1 例， $16.7 \% ， \mathrm{~b}$ で11例中 2 例, $18.2 \%, \mathrm{c}$ で18例中 5 例， $27.8 \%$ 示し，出血から手術 までの時間経過が長くなるにつれて 2 回以上の出血例の 死亡率も上昇していることがわかり，出血を起点とした 時間的経過をむって適応を決めらるように考えられる。

A,B は出血開始から手術までの期間がいるいるである が，いずれも急性大量出血がみられたため緊急手術が行 われた症例であり，Cは Ivy ら゙のいう elective surgery in convalescent period after hemorrhage が行われた症 例である，Cには死亡がないが，状態のよいときの手術 なので不思議ではない、A,B には他施設から送られてき た症例があり，出血開始から手術までの期間が極端に長 いものがある. したがって入院を起点とした時間的経過 
をもって適応を決めるには問題があるように考えられ る、 a,b,c の死亡率をみると，a と b，あるいはck大き な差があり，aの死亡率が最も低い，出血を起点とした a,b c c の方が入院を起点とする A， B，C よりる同一の 病期について正確な病態を把握できると思われる。

Ivy ら`は早期手術の死亡率は7.8\%，後期手術の死亡 率は $39.7 \%$ と述べている。これに対し，Palmer ${ }^{12)}$ は大 量出血の死亡率は内科的治療でる即時手術でも選択手術 でる同じである (Enguist) と述べている.しかし, 自験 例では出血後48時間未満の手術で80歳の症例を除き死亡 は認められなかった。したがって手術の時期は80藏以上 を除く70歳代までについては出血後48時間未満の早期手 術が安全であると考えられる.

入院を起点とした $\mathrm{A}, \mathrm{B}, \mathrm{C}$ の輸血量をみると，Cは術 前, 術中, 術後にわたり平均輸血量が1,000 $\mathrm{ml}$ 以下で 少量出血之考えられる. 術前平均輸血量は Aが B より多

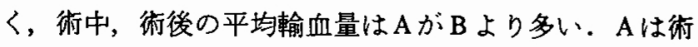

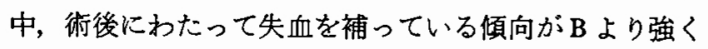
みられる.出血を起点とした $a, b ， c の$ 輸血量をみる と, 術前の平均輸血量は $\mathrm{b} か ゙$ 最も多い. しかし, 死亡率 はcが最も高い。このことは出血から手術までの時間的 経過が死亡と深く関係していることを示している.術中 の平均輸血量はbが最も多いが，a，c と大差はない。 術後の平均輸血量は $\mathrm{a} か ゙$ 断然多く, 術中, 術後にわたっ て失血を補っている傾向が強くみられる.入院を起点と しとみても, 出血を起点としてみても輸血量と死亡率と の間に一定の関係は術前, 術中, 術後にわたりみられ ず，むしろ出血からの時間的経過の方が死亡に関係して いるとみられるが, 死亡は術前, 術中の輸血量がいずれ む1,000m をこえている症例に多くみられる。

ショックの改善され奴まま手術が行われた症例ではA の方が Bより死亡率が高いが, ショック準備状態で手術 が行われた症例ではBの方がAより死亡率が高い。した がって入院を起点とした時間的経過から手術適応を決め えないように思われる.出血を起点としてみると、ショ ックが改善されぬまま手術が行われた症例の死亡は、が 最も低い.ショック準備状態の手術ではcのみに死亡が ある・ショックが改善されぬまま行われた手術でも出血 から48時間末満では80歳の症例を除き死亡はなかった。

輸血をくりかえしても循環不全が存続するときは外科 的治療の適応であると Brick $^{13}$ は述べている. しかし手 術時期に関してはふれていない.ショック状態を改善し てから手術を行うことは理想的であるが、ショック状態
を改善しえない症例も多い.ショックの場合でも出血開 始からの時間的経過を考慮して手術適応を決めることが できるように思われる。

術前合併症と死亡との関係化ついてみた。術前合併症 のある症例では A,B ともに $25 \%$ 死亡している。しか し, 出血を起点としてみると, $\mathrm{a}$ で80歳の症例を除き死 亡はない. bで33.3\%の死亡があり, c で80歳の症例を 除き $14.3 \%$ 死亡がある. b と c との死亡率の 差はbに 手術適応から除外されるべき症例があるためと考えられ る.

術前合併症を疾患別々みると, 器質的心疾患が死亡と 深く関保している。原田 ${ }^{16)}$ は慢性心不全，新鮮な心筋硬 塞, 高度冠不全を伴う肺機能不全などは一般に手術の対 象にならないと述べている。一方，Furguson ${ }^{15)}$ は冠動脈 疾患の既往をむつ患者は緊急手術がよいと述べており， 土屋 ${ }^{16)}$ は重篤な合併症 (心肺肝腎疾患, 大手術後など) のあるもの,ことに60歳以上の高龄者に対しては手術を 早目にすると述へてている，自験例からみても，心疾患を もつものは出血後48時間末満に手術を行うのが安全では ないかと思われる．持続出血，あるいは再出血に対する 保存的治療の期間中に与只られる心負荷は軽く, 短いも のでありたい．やむをえず待機しなければならない症例 でも, 持続出血, あるいは再出血をみないといら確証の ない限り出血後 7 日未満に外科的治療をすることが望ま しい.

術式は A,B,C など入院を起点としたものでも，a,b,c など出血を起点としたものでも死亡とは密接な関係はな い.

術後合併症はBでAより多くみられ，入院を起点とし たるのでは手術適応の決定がむづかしい，一方，出血を 起点としてみると, $a>c>b$ の順に多くみられる. しか し, 死亡率は $a<b<c$ の順である.この点からみても 出血を起点として早い時期に手術を行うことが安全と考 えられる。

\section{v. 結 論}

出血胃潰癔111例について, 入院を起点とした場合と, 出血を起点とした場合に死亡例を中心に時間的経過を倹 討した. 出血胃潰場の外科的治療, とくに, その手術適 応決定にあたって, 年龄, 出血回数, 手術までの期間, 輸血量, 手術とショック, 術前合併症, 術式, 術後合併 症を考慮し，出血を起点とした時間的経過によって手術 適応を決めることが望ましい，また出血より48時間未 満, ついで48時間より7日末満に手術されたものの予後 
がよい。

稿を終るにのぞみ，直接ご指導，ご校閱を睗わつた榑 原宣教授, 鈴木博孝助教授, ならびに本研究の機会を与 えご鞭檤いただいた小林誠一郎所長，遠藤光夫教授を はじめ当センター諸学兄姉に心から感謝する.

(本論文の要旨は第11回日本消化器外科学会総会にお。 いて発表した。）

\section{文献}

1) 長尾房大, 池内準次, 成川恒夫注か：外科から みた上部消化管の出血。胃と腸， $4: 145-151$, 1969.

2) 井口潔, 小林迪夫, 小川勇一郎汪加: 上部消 化管出血の外科治療。臨床と研究, $47: 2088$ 2097, 1970.

3）野建人, 曾和隔生, 山辻英也 : 大出血をとも なった胃・十二指腸潰場の手術はどうするか。 臨床外科, 22:1095-1100, 1967.

4) A.C. Ivy, M.I. Grossmann and William H. Bachrach: Peptic Ulcer, The Blakiston Company Philadelphia. Tronto, 1950964 1080.

5) H. Dalichan, E. Ungeheuer und G. Schade: Behandlungsergabnisse massiver gastrointestinaler Blutungen Medizinische Klinik, 63: 587-591, 1968.

6) A.C. Ivy, M.I. Grossmann and William H. Bachrach: Peptic Ulcer, The Blakiston Company Philadelphia. Tronto, 1950 538-603.

7) J.R. Cocks, A.M. Desmond, B.F. Swynnerton and N.C. Tanner: Partial gastrectomy for hemorrhage. Gout, 13: 331-340, 1972.

8) A.C. Ivy, M.I. Grossmann and William H. Bachrach: Peptic Ulcer, The Plakiston Company Philadelphia. Tronto, 1950 538-603 による。

9) A.C. Ivy, M.I. Grossmann and William H. Bachrach: Peptic Ulcer, The Blakiston Company Philadelphia. Tronto, 1950 538-603 K よる.

10) H.L. Bochus: Gastroenterology Vol I, 2nd edition W.B. Saunders Co. Philadelphia \& London, 1963 614-667.

11) A.C. Ivy, M.I. Grossmann and William H. Bachrach: Peptic Ulcer, The Blakiston Company Philadelphia. Tronto, 1950 538-603 K よる.

12) Eddy D. Palmer: Upper Gastrointestinal Hemorrhage Charles C Thomas. Publisher Springfield. Illinois. U.S.A. $1970161-165$.

13) Eddy D. Palmer: Upper Gastrointestinal Hemorrhage Charles C Thomas. Publisher Springfield, Illinois, U.S.A. $1970161-165 k$ 上る.

14）原田稔, 恵谷敏：胃手術のすへて 上巻, 金原出版 K. K. 東京 - 京都, 1971，183-238.

15) Gordon Furguson: Surgical management of gastroduodenal hemorrhage. Lancet, 1:228231, 1954.

19）土屋周二, 島津久明：胃十二指腸潰湟のすべ 乙, 南江堂, 東京・京都, 1971，279-290。 